\title{
Hirarki Wilayah Kota Ternate Pasca Pengembangan Kawasan Waterfront City
}

\author{
Firdawaty Marasabessy 1 \\ Universitas Khairun, Ternate, Indonesia \\ Artikel Masuk : 17 November 2016 \\ Artikel Diterima : 27 Desember 2016 \\ Tersedia Online : 30 Desember 2016
}

\begin{abstract}
Abstrak: Pengembangan waterfront city yang termuat dalam rencana tata ruang Kota Ternate tahun 2006-2015 diantaranya bermuara dari keterbatasan lahan kota dalam menyediakan infrastruktur perkotaan akibat tekanan populasi yang semakin meningkat, kondisi geografis dan topografis wilayah, ancaman bencana dari letusan gunung api serta strategi pengembangan nasional dan provinsi. Penelitian ini difokuskan untuk menganalisis hirarki atau tingkat perkembangan wilayah Kota Ternate setelah pengembangan kawasan waterfront city dengan indikator ketersediaan infrastruktur. Metodologi penelitian yang digunakan adalah metode analisis skalogram dengan variabel ketersediaan sarana dan prasarana lingkungan. Hasil penelitian menunjukkan bahwa hirarki wilayah Kota Ternate setelah pengembangan kawasan waterfront city (tahun 2005-2011) telah mengalami perkembangan dari aspek ketersediaan infrastruktur dan aksesibilitas terutama di kelurahan pesisir yang menjadi kawasan waterfront city.
\end{abstract}

Kata Kunci: hirarki wilayah, perkembangan kota, skalogram, waterfront city

\begin{abstract}
Ternate waterfront city development initiative 2006-2015 was designated for anticipating the limitation of land use due to high population increase, geographical and topographical constraints of the region, the threat of catastrophic volcanic eruption, and the national and provincial development strategies. The purpose of this study was to analyze the urban service hierarchy inside the city responding the initiative. The methodology used in this research was scalogram analysis for calculating infrastructure availability variables. The results showed that the post-implementation of waterfront city development initiative (20052011) the number of infrastructure availability and accessibility has improved, particularly in the coastal urban villages inside the waterfront city development area.
\end{abstract}

Keywords: regional hierarchy, urban growth, schalogram, waterfront city

\section{Pendahuluan}

Perkembangan kota pantai ( waterfront city) di Indonesia tidak terlepas dari pengaruh kejayaan kerajaan-kerajaan di nusantara dengan kegiatan utama berupa perdagangan, jasa dan pusat pemerintahan. Saat ini kota-kota pantai di Indonesia tumbuh dan berkembang

\footnotetext{
${ }^{1}$ Korespondensi Penulis: Universitas Khairun, Ternate, Indonesia

Email: phido_b@yahoo.co.id
} 


\section{Hirarki Wilayah Kota Ternate Pasca Pengembangan Kawasan Waterfront City}

dengan keragaman berdasarkan fungsi kota yaitu sebagai kota administratif, budaya, pendidikan, perdagangan, industri dan pariwisata (Mulyandari, 2010). Kota Ternate merupakan salah satu waterfront city di Indonesia yang awalnya dikenal dalam sejarah dunia sebagai pusat perdagangan rempah-rempah skala internasional di abad ke-15 silam. Selama menjadi kotamadya, Ternate telah menunjukkan perkembangan sebagai kota perdagangan dan industri serta kemajuan yang cukup pesat dalam penyelenggaraan pemerintahan, pelaksanaan pembagunan, dan pelayanan kepada masyarakat.

Di sisi lain, Kota Ternate dihadapkan dengan kondisi geografis wilayah yang merupakan sebuah gunung api aktif dengan kemiringan lereng terbesar diatas $40 \%$ yang mengerucut ke arah puncak gunung dan dikelilingi laut. Hal ini berdampak pada ketersediaan lahan untuk dapat dikembangkan sebagai ruang publik kota. Dengan demikian, wilayah pesisir menjadi salah satu alternatif strategis dalam pengembangan kawasan, khususnya dalam pemenuhan infrastruktur perkotaan dengan metode reklamasi pantai. Secara spasial, luas kawasan pesisir semakin bertambah, khususnya kawasan pesisir timur dan pesisir selatan yang dijadikan sebagai kawasan pengembangan waterfront. Sistem penggunaan lahan perkotaan yang didominasi oleh aktivitas manusia yang kompleks berpengaruh terhadap dinamika spasial-temporal perkembangan wilayah (Hu \& Lo, 2007). Perkembangan kota berpengaruh terhadap transformasi perubahan lahan (Nong $\& \mathrm{Du}, 2011)$.

Sebelum pengembangan kawasan waterfront, kondisi eksisting sarana dan prasarana masih terbatas cakupan pelayanannya terutama di wilyah belakang (hinterland), yaitu di Kecamatan Pulau Ternate, sebagian Kecamatan Ternate Utara, dan sebagian Kecamatan Ternate Selatan yang cenderung berada pada kondisi topografis perbukitan (upland). Ketimpangan sebaran infrastruktur menyebabkan perbedaan yang cukup signifikan antara wilayah bagian barat dan wilayah bagian timur Kota Ternate terhadap dimensi cakupan pelayanan pada masyarakat. Kondisi ini menunjukkan adanya prioritas pembangunan wilayah yang berorientasi di wilayah bagian timur sebagai kawasan cepat tumbuh dalam menghubungkan dengan pulau-pulau sekitarnya dalam lingkup lokal maupun regional.

Rencana Tata Ruang Wilayah (RTRW) Kota Ternate tahun 2006-2015 mengalokasikan wilayah pesisir timur dan selatan sebagai kawasan waterfront city yang tumbuh menjadi pusat pelayanan jasa, perdagangan, sarana ibadah, transportasi dan ruang terbuka hijau (taman kota berbasis budaya). Sebaran dan ketersediaan infrastruktur di wilayah tersebut menjadi indikator dalam menentukan hirarki perkotaan. Dengan berkembangnya kawasan waterfront city, secara tidak langsung, fungsi pusat-pusat palayan dalam skala kota ikut bergeser atau berubah. Hirarki perkotaan menggambarkan jenjang fungsi perkotaan sebagai akibat perbedaan jumlah, jenis, dan kualitas dari fasilitas pelayanan yang tersedia di kota. Hirarki perkotaan menyatakan tempat-tempat konsentrasi yang umumnya berupa daerah perkotaan tersebar di suatu wilayah atau negara dengan penduduk (besarnya kota) yang tidak sama (Tarigan, 2004).

Perkembangan suatu wilayah perkotaan dapat diukur dari tingkat ketersediaan infrastruktur atau fasilitas pelayanan yang ada. Menurut Rustiadi, Saefulhakim, \& Panuju (2009), metode praktis yang dapat digunakan untuk mengukur perkembangan suatu wilayah (hirarki) adalah dengan menghitung jumlah dan jenis sarana prasarana pelayanan (infrastruktur) yang ada pada suatu wilayah. Christaller (1933, dalam Adisasmita, 2015), dalam teorinya mengenai teori tempat sentral (central place theory) mengemukakan bahwa dalam penentuan hirarki kota-kota dalam suatu wilayah dapat dilakukan dengan cara meninjau jumlah pelayanan yang dapat diemban oleh sebuah kota.

Suatu ciri umum dari daerah-daerah nodal (Christaller, 1933 dalam Adisasmita, 2015) adalah bahwa penduduk kota tidaklah tersebar secara merata di antara pusat-pusat yang sama besarnya, tetapi tersebar di antara pusat-pusat yang besarnya berbeda-beda dan secara keseluruhan membentuk suatu hirarki perkotaan (urban hierarchy). Akan tetapi, jika 
hirarki itu sudah terbentuk maka akan berdampak pada dominannya pusat-pusat yang lebih besar dan aglomerasi arus fenomena ekonomi yang mencirikan daerah-daerah nodal. Ini berarti bahwa untuk menjelaskan evolusi hirarki perkotaan adalah unsur yang sangat penting untuk dapat memahami daerah-daerah nodal.

Menurut teori tempat sentral, fungsi-fungsi pokok suatu pusat kota adalah bertindak sebagai pusat pelayanan bagi daerah belakangnya, mensuplai barang-barang dan jasa-jasa sentral seperti jasa eceran, perdagangan, perbankan, fasilitas pendidikan, hiburan dan kebudayan dan pelayanan pemerintah kota. Pusat-pusat yang lebih tinggi ordenya/hirarkinya melayani pusat-pusat yang lebih rendah hirarkinya dan antara pusatpusat yang hirarkinya sama tidak saling melayani. Tujuan penelitian ini adalah untuk identifikasi tingkat perkembangan wilayah Kota Ternate dalam kurun waktu setelah pengembangan kawasan waterfront yang ditinjau dari hirarki wilayah perkotaan berdasarkan karakteristik wilayah yang dimiliki.

\section{Metode Penelitian}

Salah satu cara untuk mengukur hirarki wilayah secara cepat dan mudah adalah menggunakan metode skalogram. Metode skalogram digunakan untuk menganalisis tingkat perkembangan suatu wilayah. Asumsi yang digunakan adalah bahwa wilayah yang memiliki rangking tertinggi adalah lokasi yang dapat menjadi pusat pelayanan. Berdasarkan analisis ini dapat ditentukan prioritas pengadaan sarana prasarana di setiap unit wilayah yang dianalisis dari tingkat perkembangan wilayahnya.

Urutan hirarki yang diperoleh berdasarkan akumulatif masing-masing kelurahan, yang kemudian dikelompokkan menjadi 3 (tiga) kelas, yaitu hirarki 1 (tingkat perkembangan kelurahan atau desa maju), hirarki 2 (tingkat perkembangan kelurahan atau desa sedang), dan hirarki 3 (tingkat perkembangan kelurahan atau desa rendah). Penentuan pengelompokkan didasarkan pada nilai standar deviasi Indeks Perkembangan (IP) dan nilai-rata-rata dari IP.

Data Potensi Desa (PODES) yang digunakan meliputi data dalam beberapa kurun waktu yakni tahun 2005, tahun 2006, tahun 2008 dan tahun 2011. Keempat titik tahun tersebut dimaksudkan untuk melihat tren perkembangan selama masa periode setelah pengembangan kawasan waterfront. Pengembangan kawasan waterfront dimulai pada tahun 2001, sehingga untuk menganalisis kawasan atau kelurahan atau desa mana yang ikut berkembang seiring dengan perkembangan waterfront, maka dibutuhkan minimal 2 (dua) titik tahun (setelah tahun 2001) sebagai pembanding. Variabel yang digunakan untuk menganalisis hirarki wilayah sebanyak 35 variabel yang terdiri dari kategori variabel aksesibilitas dan jumlah saran pendidikan, kesehatan, peribadatan, dan niaga perdagangan. Rincian mengenai penggunaan variabel yang digunakan terlihat di Tabel 1.

Tabel 1. Variabel untuk Analisis Hirarki Wilayah

\begin{tabular}{cl}
\hline No. & \multicolumn{1}{c}{ Variabel } \\
\hline 1. & Jumlah Penduduk \\
2. & Luas kelurahan/desa \\
3. & Jarak dari desa ke ibukota kecamatan \\
4. & Waktu tempuh dari desa ke ibukota kecamatan \\
5. & Jarak dari desa ke ibukota kabupaten \\
6. & Waktu tempuh dari desa ke ibukota kabupaten \\
7. & Jarak dari desa ke ibukota kabupaten/kota lain terdekat \\
8. & Waktu tempuh dari desa ke ibukota kabupaten/kota lain terdekat \\
9. & Jumlah TK \\
\hline
\end{tabular}




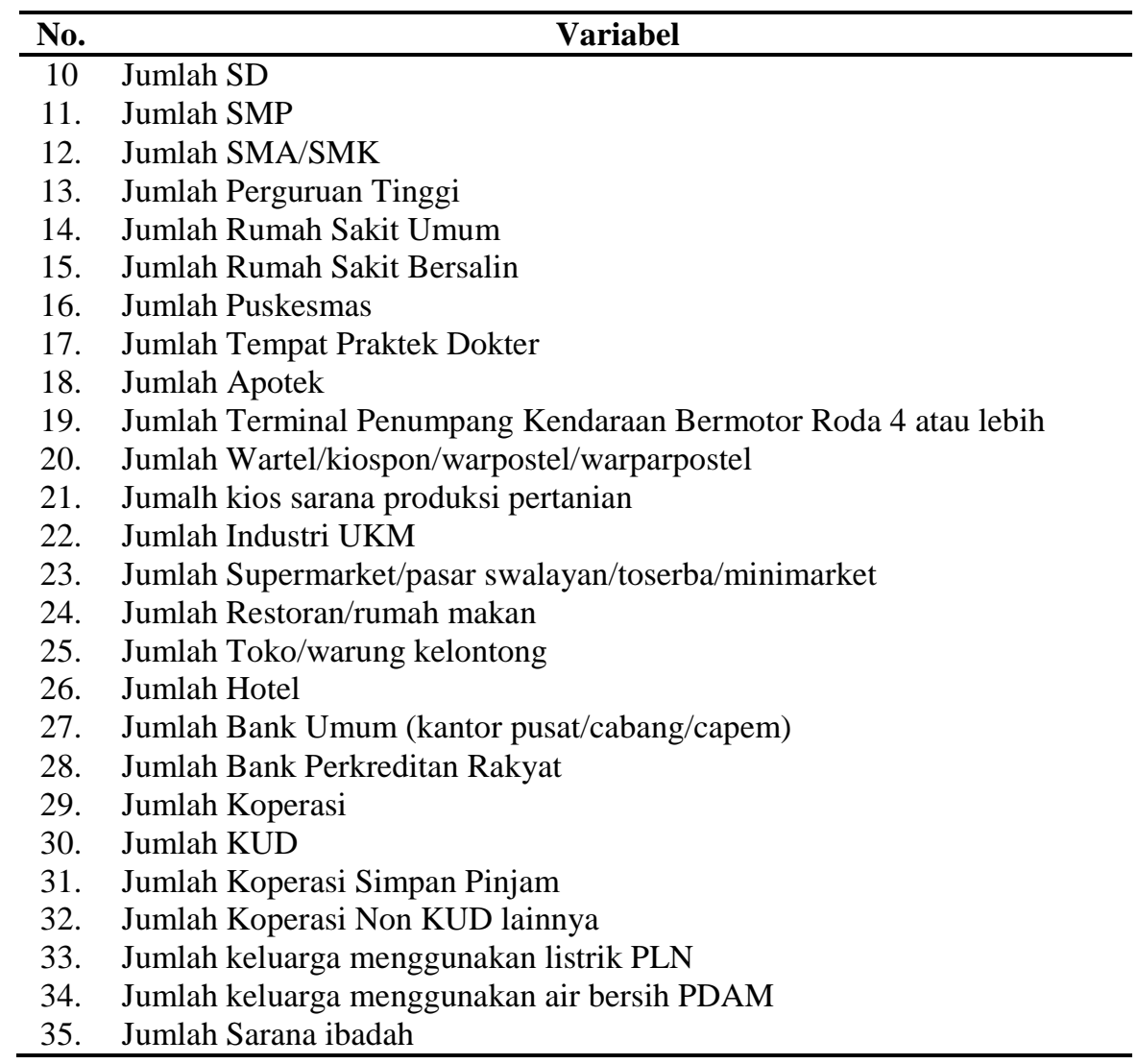

\section{Hasil dan Pembahasan}

\section{Lokasi Penelitian}

Lokasi penelitian berada di Kota Ternate, Provinsi Maluku Utara dengan letak geografis pada $0^{\circ}-2^{\circ}$ LU dan $126^{\circ}-128^{\circ}$ BT dengan batas administratif sebelah utara, barat dan selatan berbatasan dengan Laut Maluku, dan sebelah timur berbatasan dengan Selat Halmahera. Secara administratif Kota Ternate terdiri dari kawasan kepulauan (lihat Tabel 2) dengan luas daratan $250,85 \mathrm{~km}^{2}$ dan luas lautan $5.547,55 \mathrm{~km}^{2}$ yang terbagi dalam 7 kecamatan dan 77 kelurahan/desa. Jumlah penduduk sebanyak 185.705 jiwa yang terkonstentrasi di 3 kecamatan yang merupakan wilayah yang padat penduduknya, yaitu Kecamatan Ternate Tengah, Kecamatan Ternate Selatan, dan Kecamatan Ternate Utara.

Lokasi penelitian difokuskan pada Pulau Ternate, yang terdiri dari 4 (empat) kecamatan, yakni kecamatan Pulau Ternate, kecamatan Ternate Selatan, kecamatan Ternate Tengah dan kecamatan Ternate Utara. Hal ini berkaitan dengan pengembangan kawasan waterfront yang terdapat di sekitar lokasi tersebut, sehingga untuk melihat perkembangan wilayah berdasarkan ketersediaan sarana dan prasarana hanya dibatasi pada kecamatan-kecamatan yang disebutkan diatas. Kawasan yang menjadi daerah pengembagan kawasan waterfront city tepatnya berada di Kecamatan Ternate Tengah, yaitu pada 6 kelurahan meliputi kelurahan Gamalama, Kelurahan Muhajirin, Kelurahan Kota Baru, Kelurahan Takoma, Kelurahan Makassar Timur, dan Kelurahan Salero. Gambar 1 menunjukkan lokasi penelitian. 
Tabel 2. Wilayah Administrasi Kota Ternate

\begin{tabular}{lcccc}
\hline Kecamatan & $\begin{array}{c}\text { Luas Daratan } \\
\left(\mathbf{k m}^{2}\right)\end{array}$ & $\begin{array}{c}\text { Jumlah } \\
\text { Kelurahan/ } \\
\text { Desa Pesisir }\end{array}$ & $\begin{array}{c}\text { Jumlah } \\
\text { Kelurahan/ Desa } \\
\text { Non-Pesisir }\end{array}$ & $\begin{array}{c}\text { Jumlah } \\
\text { Penduduk } \\
(\text { Jiwa) }\end{array}$ \\
\hline Pulau Ternate & 66,58 & 12 & 1 & 14.692 \\
Moti & 24,60 & 6 & - & 4.399 \\
Pulau Batang Dua & 101,05 & 6 & - & 2.487 \\
Pulau Hiri & 6,70 & 6 & - & 2.735 \\
Ternate Selatan & 19,44 & 11 & 6 & 63.746 \\
Ternate Tengah & 18,52 & 7 & 8 & 52.072 \\
Ternate Utara & 14,16 & 11 & 3 & 45.574 \\
\hline Jumlah & $\mathbf{2 5 0 , 8 5}$ & $\mathbf{5 6}$ & $\mathbf{2 1}$ & $\mathbf{1 8 5 . 7 0 5}$ \\
\hline
\end{tabular}

Sumber: BPS Kota Ternate dalam Angka 2011

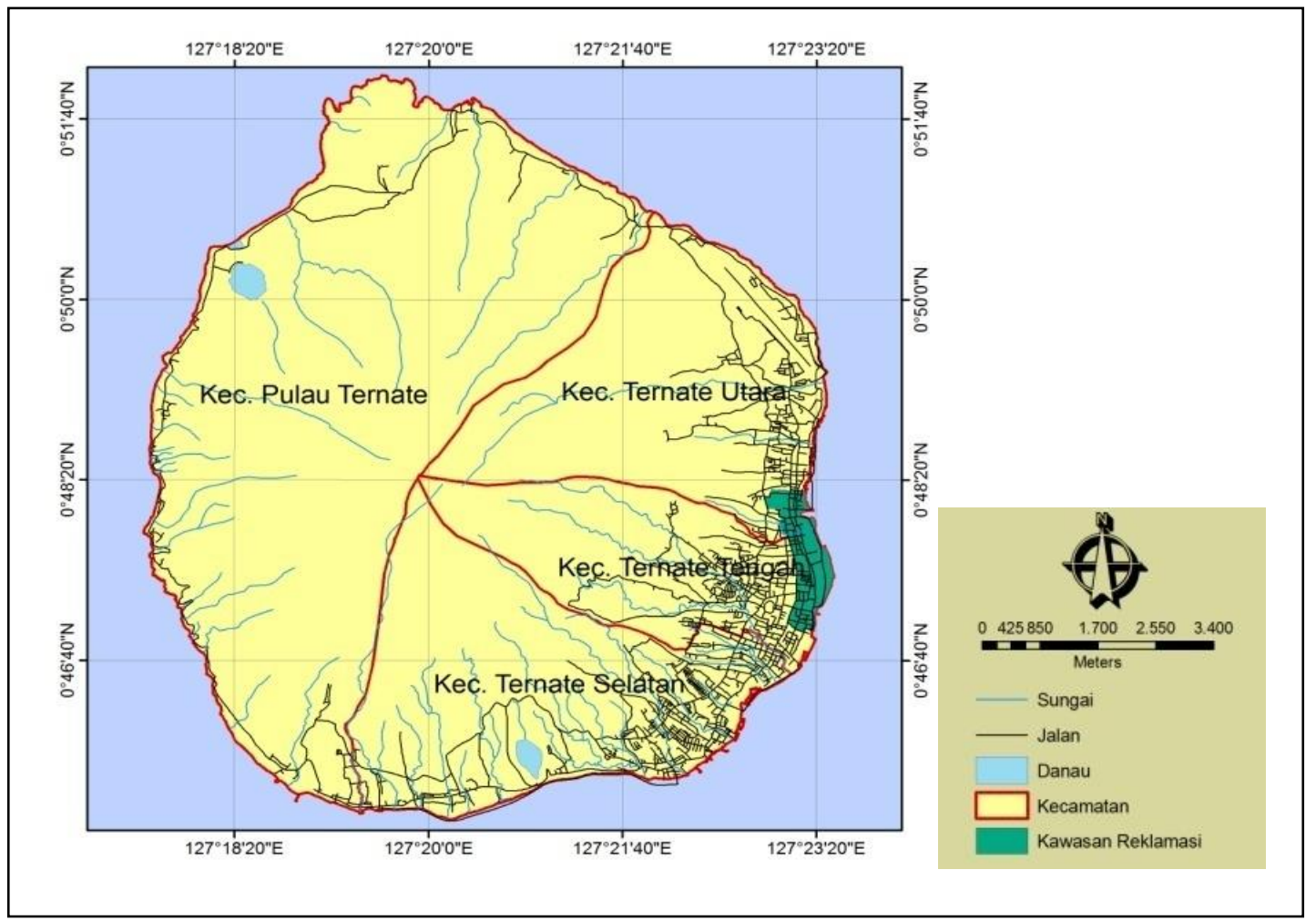

Sumber: Analisis Penulis, 2014

\section{Gambar 1. Lokasi Penelitian}

\section{Sebaran Sarana dan Prasarana Wilayah}

Sebaran sarana dan prasarana di Kota Ternate terkonsentrasi di wilayah yang dekat dengan pusat kota. Kawasan pusat kota terletak pada Kecamatan Ternate Tengah. Berdasarkan data BPS (2011), menunjukkan bahwa sebaran fasilitas pelayanan terbanyak jumlahnya berada di Kecamatan Ternate Tengah. Ini menujukkan bahwa Kecamatan Ternate Tengah sebagai wilayah nodal yang nantinya melayani kegiatan-kegiatan bagi wilayah-wilayah yang lebih rendah hirarkinya atau yang paling sedikit fasilitas pelayanannya. Ketersediaan sarana dan prasarana baru di kawasan pengembangan 
waterfront city yang tepat berada di Kecamatan Ternate Tengah ikut berperan dalam meningkatnya jumlah sarana dan prasarana wilayah.

Keterbatasan fasilitas pelayanan di Kecamatan Pulau Ternate berkorelasi dengan jumlah penduduk. Ketersediaan fasilitas pelayanan di kecamatan ini terbilang lebih sedikit dibanding kecamatan lainnya. Cakupan fasilitas pelayanan (lihat Tabel 3) yang tersebar di 13 kelurahan dapat melayani 14.692 jiwa. Namun demikian, fasilitas kesehatan perlu mendapat perhatian, mengingat ketersediaan hanya terdapat 1 unit yang harus melayani masyarakat di kecamatan tersebut. Sebaran lokasi sarana dan prasarana di Kota Ternate terlihat di Gambar 2.

Tabel 3. Sebaran Sarana dan Prasana di Kota Ternate Tahun 2011

\begin{tabular}{lcccccc}
\hline \multicolumn{1}{c}{ Kecamatan } & $\begin{array}{c}\text { Fasilitas } \\
\text { Kesehatan }\end{array}$ & $\begin{array}{c}\text { Fasilitas } \\
\text { Pendidikan }\end{array}$ & $\begin{array}{c}\text { Fasilitas } \\
\text { Ekonomi }\end{array}$ & $\begin{array}{c}\text { Fasilitas } \\
\text { Pemerintahan }\end{array}$ & $\begin{array}{c}\text { Fasilitas Sosial } \\
\text { Peribadatan }\end{array}$ & Jumlah \\
\hline Pulau Ternate & 1 & 34 & 218 & 13 & 43 & $\mathbf{3 0 9}$ \\
Ternate Selatan & 22 & 57 & 869 & 21 & 80 & $\mathbf{1 . 0 4 9}$ \\
Ternate Tengah & 54 & 56 & 1480 & 19 & 80 & $\mathbf{1 . 6 8 9}$ \\
Ternate Utara & 11 & 45 & 789 & 14 & 72 & $\mathbf{9 3 1}$ \\
\hline Jumlah & $\mathbf{8 8}$ & $\mathbf{1 9 2}$ & $\mathbf{3 3 5 6}$ & $\mathbf{6 7}$ & $\mathbf{2 7 5}$ & \\
\hline
\end{tabular}

Sumber: Kota Ternate dalam Angka 2011

Tabel 3 menunjukkan bahwa fasilitas ekonomi memegang peran penting dalam perkembangan kota. Fasilitas ekonomi tumbuh signifikan seiring dengan perkembangan kota, dimana Kota Ternate sebagai pusat jasa dan perdagangan bagi kawasan regional di Maluku Utara. Oleh karena itu, tidak menutup kemungkinan bahwa perkembangan sarana ekonomi cenderung lebih cepat berkembang pesat dibandingkan fasilitas pelayanan lainnya. Fasilitas ekonomi terkonsentrasi di kecamatan Ternate Tengah yang merupakan kawasan waterfront city.

Fasilitas kesehatan, seperti puskesmas, puskesmas pembantu dan posyandu merupakan standar pelayanan minimum kesehatan masyarakat yang wajib disediakan di setiap kecamatan. Berdasarkan data di Tabel 3, Kecamatan Pulau Ternate mengalami keterbatasan dalam pelayanan fasilitas kesehatan. Sementara itu, sarana dan prasarana kesehatan lainnya misalnya rumah sakit, rumah sakit bersalin, balai pengobatan, tempat praktek dokter maupun apotek hanya terpusat pada wilayah yang berada di pusat kota, yakni kecamatan Ternate Tengah dan kecamatan Ternate Selatan. Ini menujukkan bahwa kedua kecamatan tersebut merupakan wilayah nodal terhadap fasilitas kesehatan bagi wilayah belakangnya.

Perkembangan fasilitas ekonomi dan fasilitas sosial di kawasan waterfront city mendorong pertumbuhan pusat-pusat kegiatan khususnya untuk pelayanan pusat perbelanjaan, pasar tradisional, dan ruko-ruko yang banyak tersedia di kawasan ini. Di sisi lain, fasilitas sosial, seperti sarana ibadah serta sarana rekreasi dan olahraga juga dibangun di kawasan ini. Kecenderungan terpusatnya fasilitas pelayanan di kawasan waterfront city mengindikasikan bahwa terjadi perkembangan yang cukup signifikan di wilayah nodal, yaitu dalam kawasan maupun sekitar kawasan.

Fasilitas pelayanan yang tersebar merata ke seluruh kecamatan diantaranya adalah fasilitas pendidikan, fasilitas ekonomi, dan fasilitas sosial peribadatan. Fasilitas pemerintahan dan fasilitas kesehatan terkonsentrasi di pusat kota mencakup Kecamatan Ternate Tengah dan Kecamatan Ternate Selatan. Peta sebaran sarana dan prasarana yang ditunjukkan di Gambar 2 menunjukkan bahwa aglomerasi pusat kegiatan terdapat pada 3 kecamatan, yakni Kecamatan Ternate Tengah, Kecamatan Ternate Selatan dan Kecamatan Ternate Utara yang berkorelasi positif dengan tingkat kepadatan penduduk. 


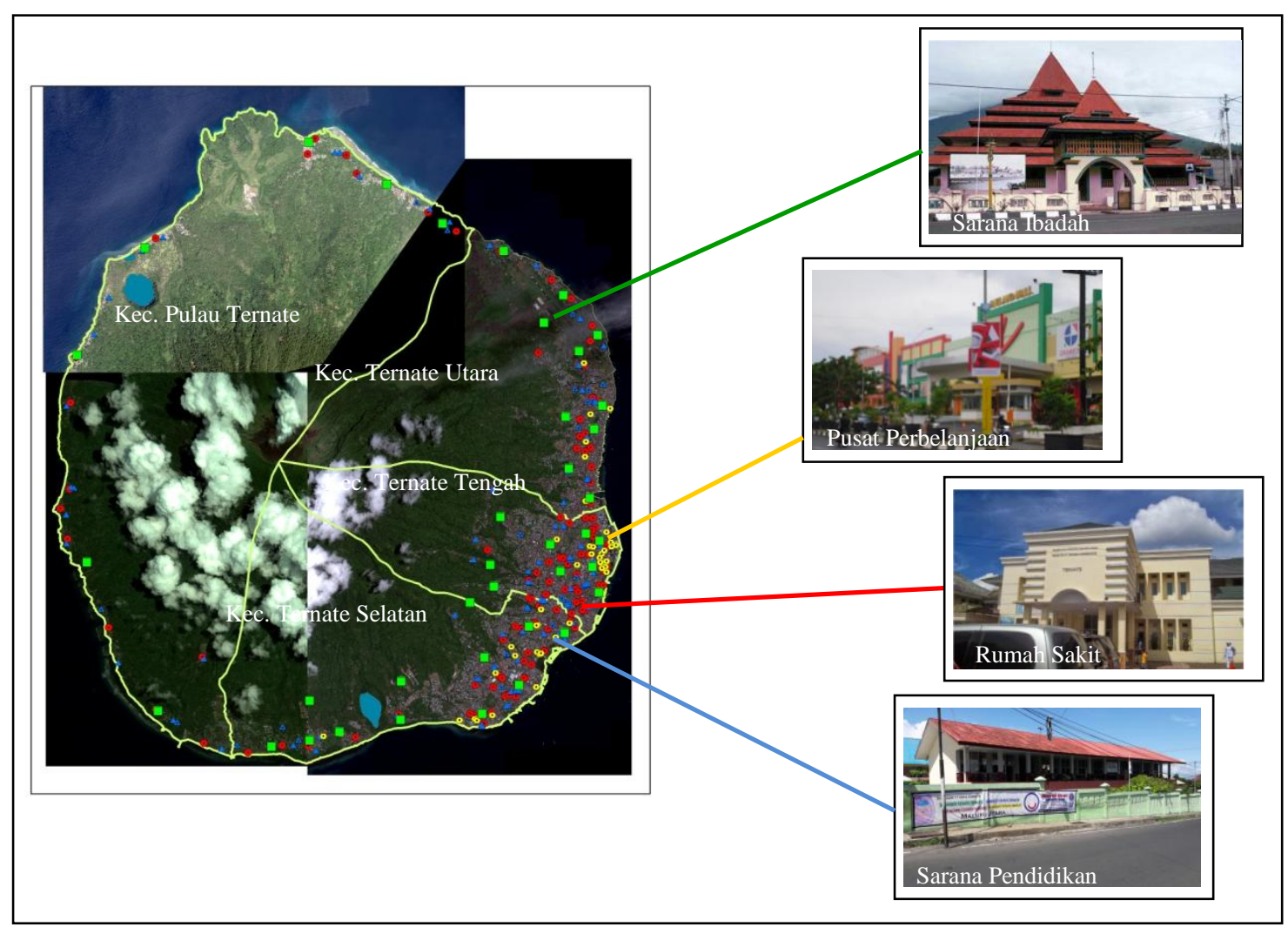

Sumber: Analisis Penulis, 2014

\section{Gambar 2. Peta Sebaran Sarana dan Prasarana di Kota Ternate}

Fungsi dan hirarki Kota Ternate merupakan tata jenjang yang menunjukkan hubungan keterkaitan antara komponen pembentuk struktur pemanfaatan ruang. Penentuan fungsi kota pada prinsipnya didasarkan pada komponen pembentuk yang dominan mempengaruhi aktivitas sosial ekonomi perkotaan, sedangkan hirarki kota adalah hubungan antar kegiatan yang berpengaruh terhadap pola pemanfaatan ruang dalam skala wilayah yang dikenal dengan sistem kota atau orde kota berdasarkan skala pelayanan.

Perkotaan berperan besar dalam persebaran dan pergerakan penduduk. Hal ini terjadi karena di bagian wilayah tersebut terdapat berbagai kegiatan ekonomi sekunder dan tersier serta fungsi pelayanan yang menimbulkan daya tarik bagi penduduk. Disisi lain pengelompokkan kegiatan, fasilitas dan penduduk serta berpusatnya berbagai kegiatan yang menyangkut publik di kawasan waterfront city merupakan faktor-faktor yang menarik bagi kegiatan ekonomi/ bisnis. Kota Ternate memiliki nilai strategis, tidak hanya sebagai pemusatan penduduk, tetapi juga sebagai pusat berbagai fungsi sosial-ekonomi-politik dan administrasi, serta berpotensi sebagai instrumen untuk mencapai tujuan-tujuan pembangunan pada tingkat regional maupun nasional.

\section{Hirarki Wilayah Kota Ternate}

Struktur ruang wilayah kota merupakan kerangka sistem pusat-pusat pelayanan kegiatan kota yang berhirarki dan satu sama lain dihubungkan oleh sistem jaringan prasarana wilayah kota. Struktur ruang wilayah kota berfungsi sebagai pembentuk sistem pusat-pusat pelayanan wilayah kota yang memberikan layanan bagi wilayah kota dan juga 
sebagai arahan penempatan jaringan prasarana wilayah kota sesuai dengan fungsi jaringannya yang menunjang keterkaitan antar pusat-pusat pelayanan kota.

Pada tatanan wilayah Kota Ternate, fungsi pelayanan primer diemban oleh Kecamatan Ternate Tengah, Kecamatan Ternate Selatan dan Kecamatan Ternate Utara yang dicirikan dengan ketersediaan fasilitas pelayanan terhadap seluruh wilayah pengembangannya terutama dalam konteks pelayanan administrasi pemerintah. Sementara itu, fungsi pelayanan sekunder diemban oleh masing-masing kecamatan di Pulau Ternate, Moti, Pulau Hiri dan Pulau Batang Dua yang memiliki jangkauan pelayanan terhadap wilayah pengembangan pusat (central) ruang kota.

Pusat Pelayanan Kota (PPK) Kota Ternate memiliki arahan dan fungsi pengembangan sebagai pengembangan pusat pelayanan pemerintah kota, pendidikan dan olahraga, perdagangan dan jasa, pusat pelayanan transportasi, pusat pelayanan kesehatan, pusat keamanan, dan pusat sejarah dan kebudayaan. Pusat Pelayanan Kota (PPK) berperan untuk melayani seluruh wilayah kota dan/ atau regional. PPK di Kota Ternate terletak di sebagian Kecamatan Ternate Tengah meliputi Kelurahan Gamalama, Kelurahan Muhajirin, Kelurahan Tanah Raja, Kelurahan Takoma, Kelurahan Maliaro, dan Kelurahan Tanah Tinggi; sebagian Kecamatan Ternate Selatan mencakup Kelurahan Kota Baru, Kelurahan Toboko, Kelurahan Mangga Dua, dan Kelurahan Bastiong; dan sebagian Kecamatan Ternate Utara, yaitu Kelurahan Salero, Kelurahan Soa, Kelurahan Makassar Timur, dan Kelurahan Makassar Barat. Kelurahan-kelurahan yang tersebut merupakan kawasan pengembangan waterfront city.

Sub Pusat Pelayanan Kota (PPK) merupakan pusat pelayanan kegiatan kota dengan lingkup wilayah pelayanan sebagian pengembangan wilayah kota sebagaimana diatur dalam rencana perwilayahan kota. Sub PPK memiliki arahan dan fungsi pengembangan yang ditujukan sebagai pusat pelayanan pemerintahan kecamatan, pendidikan, perdagangan dan jasa, pelayanan transportasi, kesehatan, keamanan, dan pusat kebudayaan. Sub Pusat Pelayanan di Kota Ternate terbagi dalam enam sub pusat pelayanan meliputi wilayah di Kelurahan Dufa-dufa (Kecamatan Ternate Utara), Kelurahan Bastiong (Kecamatan Ternate Selatan), Kelurahan Jambula (Kecamatan Ternate Selatan), Kelurahan Moti Kota (Kecamatan Pulau Moti), Kelurahan Faudu (Kecamatan Pualu Batang Dua) dan Kelurahan Mayau (Kecamatan Pulau Hiri).

Perubahan hirarki Kota Ternate dengan unit analisis pada kelurahan/desa dapat ditentukan melalui metode skalogram. Hasil analisis untuk data PODES tahun 2005 hingga tahun 2011 menunjukkan terjadinya perubahan yang signifikan bagi wilayah-wilayah nodal atau wilayah-wilayah yang tingkat hirarki $1 /$ orde 1 . Pada data tahun 2005, sebanyak 6 kelurahan berada pada hirarki 1, sebanyak 12 kelurahan berada dalam hirarki 2, dan sebanyak 30 kelurahan berada pada hirarki 3 dari total 48 kelurahan yang ada di Kota Ternate. Sementara itu, pada tahun 2011, jumlah kelurahan yang masuk pada hirarki 1 berjumlah 7 kelurahan, hirarki 2 sebanyak 18 kelurahan, dan hirarki 3 sebanyak 35 kelurahan. Tabel 3 menunjukkan hirarki wilayah Kota Ternate tahun 2005-2011 secara lebih rinci. Peta di Gambar 4 menunjukkan peta hirarki wilayah di Kota Ternate.

Tabel 3. Hirarki Wilayah Kota Ternate Tahun 2005-2011

\begin{tabular}{cclccc}
\hline Tahun & $\begin{array}{c}\text { Hirarki } \\
\text { Wilayah }\end{array}$ & $\begin{array}{c}\text { Jenis } \\
\text { Kelurahan }\end{array}$ & $\begin{array}{c}\text { Banyaknya } \\
\text { Kelurahan/ Desa }\end{array}$ & $\begin{array}{c}\text { Indeks } \\
\text { Perkembangan (IP) }\end{array}$ & $\begin{array}{c}\text { Jumlah } \\
\text { Jenis }\end{array}$ \\
\hline \multirow{2}{*}{$\mathbf{2 0 0 5}$} & Hirarki 1 & Pesisir & 3 & $>34,84$ & 123 \\
& & Non-Pesisir & 3 & & \\
& Hirarki 2 & Pesisir & 7 & $25,10-34,84$ & 213 \\
& & Non-Pesisir & 5 & & \\
& Hirarki 3 & Pesisir & 22 & $<25,10$ & 428
\end{tabular}




\begin{tabular}{|c|c|c|c|c|c|}
\hline Tahun & $\begin{array}{l}\text { Hirarki } \\
\text { Wilayah }\end{array}$ & $\begin{array}{c}\text { Jenis } \\
\text { Kelurahan }\end{array}$ & $\begin{array}{c}\text { Banyaknya } \\
\text { Kelurahan/Desa }\end{array}$ & $\begin{array}{c}\text { Indeks } \\
\text { Perkembangan (IP) }\end{array}$ & $\begin{array}{c}\text { Jumlah } \\
\text { Jenis }\end{array}$ \\
\hline \multirow{6}{*}{2006} & Hirarki 1 & Pesisir & 3 & \multirow{2}{*}{$>35,50$} & \multirow{2}{*}{124} \\
\hline & & Non-Pesisir & 3 & & \\
\hline & Hirarki 2 & Pesisir & 7 & \multirow{2}{*}{$25,32-35,50$} & \multirow{2}{*}{194} \\
\hline & & Non-Pesisir & 4 & & \\
\hline & Hirarki 3 & Pesisir & 22 & \multirow{2}{*}{$<25,32$} & \multirow{2}{*}{440} \\
\hline & & Non-Pesisir & 9 & & \\
\hline \multirow{6}{*}{2008} & Hirarki 1 & Pesisir & 6 & \multirow{2}{*}{$>32,09$} & \multirow{2}{*}{213} \\
\hline & & Non-Pesisir & 5 & & \\
\hline & Hirarki 2 & Pesisir & 8 & \multirow{2}{*}{$23,90-32,09$} & \multirow{2}{*}{281} \\
\hline & & Non-Pesisir & 8 & & \\
\hline & Hirarki 3 & Pesisir & 28 & \multirow[t]{2}{*}{$<23,90$} & \multirow{2}{*}{456} \\
\hline & & Non-Pesisir & 8 & & \\
\hline \multirow{5}{*}{2011} & Hirarki 1 & $\begin{array}{l}\text { Pesisir } \\
\text { Non-Pesisir }\end{array}$ & $\begin{array}{l}6 \\
1\end{array}$ & $>33,90$ & 122 \\
\hline & Hirarki 2 & Pesisir & 8 & \multirow{2}{*}{$24,48-33,90$} & \multirow{2}{*}{316} \\
\hline & & Non-Pesisir & 10 & & \\
\hline & Hirarki 3 & Pesisir & 24 & \multirow{2}{*}{$<24,48$} & \multirow{2}{*}{511} \\
\hline & & Non-Pesisir & 11 & & \\
\hline
\end{tabular}

Sumber: Hasil Analisis, 2014

Hasil analisis Tabel 3 dapat dideskripsikan sebagai berikut:

1. Hirarki 1 sebagai wilayah nodal atau Pusat Pelayanan Kota (PPK) yang dicirikan oleh banyaknya ketersediaan sarana dan prasarana yang memadai, terutama sarana pendidikan, kesehatan, peribadatan, dan sarana perdagangan dengan 122 jumlah jenis (tahun 2011) serta aksesibilitas yang mudah. Pada tahun 2005, hirarki 1 terdapat 6 kelurahan yang terdiri dari 3 kelurahan pesisir dan 3 kelurahan non-pesisir yang kemudian berkembang pada tahun 2011 yang tujukan dengan peningkatan hirarki 1 sebanyak 7 kelurahan yang terdiri dari 6 kelurahan pesisir dan 1 kelurahan non-pesisir. Keenam kelurahan pesisir tersebut adalah Kelurahan Takoma, Kelurahan Kota Baru, Kelurahan Gamalama, Kelurahan Muhajirin, Kelurahan Tanah Raja, dan Kelurahan Dufa-dufa. Kelurahan pesisir tersebut merupakan kawasan pengembangan waterfront city.

2. Hirarki 2 sebagai wilayah Sub PPK dicirikan dengan kerersediaan infrastruktur lebih sedikit dibandingkan hirarki 1. Pada tahun 2005, terdapat 12 kelurahan yang termasuk dalam hirarki ini meliputi 7 kelurahan pesisir dan 5 kelurahan non-pesisir. Pada tahun 2011 bertambah 18 kelurahan yang termasuk dalam hirarki ini mencakup 7 kelurahan pesisir dan 5 kelurahan non-pesisir. Dari 7 kelurahan pesisir yang masuk ke dalam hirarki ini, 2 kelurahan di antaranya masih merupakan kawasan waterfront city, yakni Kelurahan Toboko dan Kelurahan Bastiong. Jumlah jenis sarana dan prasarana pun ikut berkembang dari awalnya tahun 2005 sebanyak 213 menjadi 316 pada tahun 2011.

3. Hirarki 3 sebagai wilayah hinterland (wilayah belakang) yang ditunjukan oleh tingkat sarana dan prasarana yang relatif sangat kurang dibanding hirarki 1 dan hirarki 2. Jumlah jenis sarana dan prasarana pada hirarki 3 ikut berkembang, dimana pada tahun 2005 hanya terdapat 428 jenis bertambah pada tahun 2011 sebanyak 551 jenis. Pada hirarki 3 untuk data tahun 2005, terdapat 30 kelurahan, dimana 22 kelurahan pesisir dan 8 kelurahan non-pesisir. Sementara itu, untuk data tahun 2011, jumlah kelurahan pesisir yang masuk ke hirarki 3 sebanyak 24 kelurahan dan kelurahan non-pesisir sebanyak 11 kelurahan. 
Hasil analisis data PODES tahun 2011 menunjukkan nilai standar deviasi (Stdev) IP 9,41 dan nilai rata-rata 24,48. Angka tersebut menggambarkan adanya peningkatan dibandingkan dengan tahun sebelumnya misalnya tahun 2008 dengan nilai Stdev IP 8,18 dan nilai rataan 23,90 serta tahun 2005 nilai Stdev IP 9,25 dan nilai rataan 25,04. Sementara itu, untuk tahun 2006, nilai Stdev IP dan nila rataan lebih tinggi dari tahun 2001 dan tahun 2008, yaitu masing-masing 9,73 dan 25,10 (lihat Gambar 3).

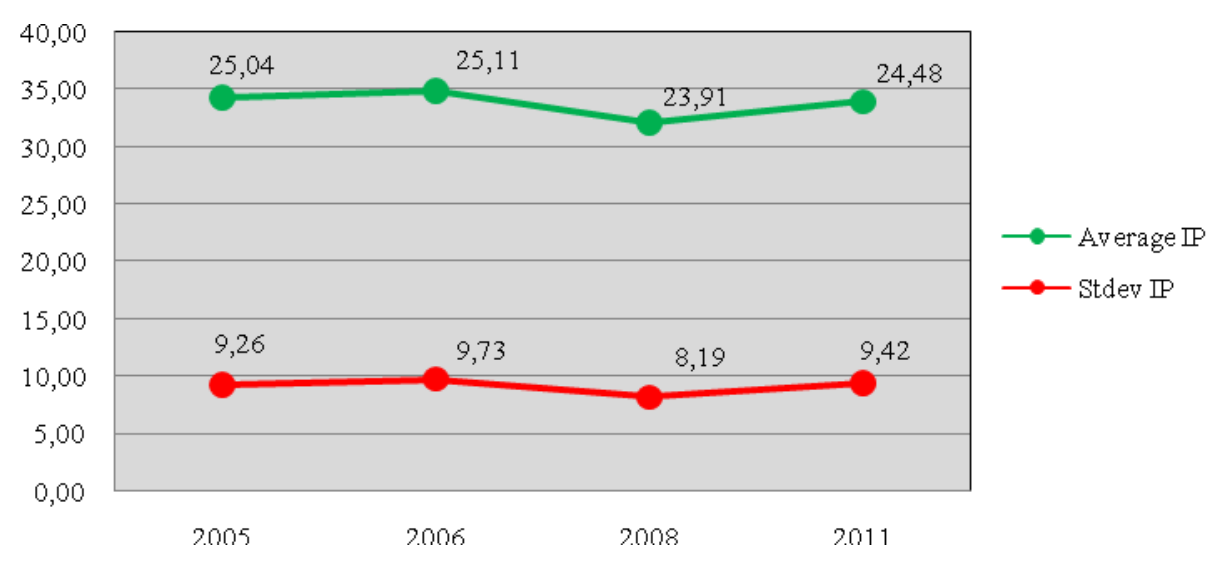

Sumber: Analisis Penulis, 2014

Gambar 3. Nilai Standar Deviasi dan Nilai Rataan Indeks Perkembangan

Nilai indeks perkembangan (IP) yang tinggi menunjukkan tingkat perkembangan wilayah misalnya dalam unit kelurahan/ desa berada dalam hirarki tertinggi atau tingkat perkembangan yang maju. Ini ditandai dengan ketersediaan infrastruktur yang banyak dalam kategori jumlah jenis dan akses pencapaian ke sarana tersebut sangat mudah. Sementara itu, untuk nilai indeks perkembangan yang rendah menunjukkan tingkat perkembangan di unit wilayah tersebut sangat rendah, faktor ketersediaan infrastruktur dalam jumlah sedikit jenisnya serta aksesibilitas sangat sulit. Secara keseluruhan tingkat perkembangan dari keempat titik tahun yang tersaji dalam Gambar 3 memperlihatkan bahwa ada peningkatan hingga tahun 2011. Ini berarti hingga tahun 2011, jumlah ketersediaan infrastruktur yang ada semakin meningkat dan akses ke sarana prasarana sangat mudah jika ditinjau dari jarak maupun waktu tempuh.

Seiring perkembangan kawasan waterfront, banyak kelurahan pesisir yang ikut berkembang sebagai Pusat Pelayanan Kota (PPK) yang melayani kebutuhan masyarakat kota. Jumlah kelurahan pesisir yang pada tahun 2011 yang berkembang menjadi hirarki 1 sebanyak 6 kelurahan, hirarki 2 sebanyak 8 kelurahan dan hirarki 3 sebanyak 24 kelurahan. Meskipun jumlah kelurahan yang berkembang masih dalam jumlah minim, namun kawasan pesisir tumbuh sebagai kawasan strategis baru dalam penyediaan kapasitas sarana dan prasarana yang menunjang wilayah perkotaan.

Adanya pengembangan kawasan waterfront di wilayah pesisir yang berada di 6 kelurahan, yaitu Kelurahan Gamalama, Kelurahan Muhajirin, Kelurahan Soasio, Kelurahan Makassar Timur, Kelurahan Kota Baru, dan Kelurahan Toboko, maka penggunaan pola ruang kawasan pesisir ikut berkembang. Setelah munculnya kebijakan dalam penataan kawasan pertumbuhan ekonomi baru, maka kawasan tersebut dipilih karena dianggap strategis dan memiliki nilai ekonomis yang tinggi serta berperan untuk memperbaiki kualitas lingkungan pesisir. Hal ini sesuai dengan pendapat Hu \& Lo (2007) bahwa aktivitas manusia berkorelasi dengan dinamika spasial-temporal perkembangan wilayah. Ukuran 
kota berkorelasi dengan jumlah populasi dan aktivitas yang terjadi di dalamnya, dimana peningkatan ketersediaan fasilitas dan infrastruktur kota juga diperlukan (Mutlu, 1988). Output dari kegiatan pengembangan kawasan waterfront city berpengaruh terhadap kualitas dan kuantitas fasilitas pelayanan yang bermuara pada perkembangan wilayahwilayah nodal/ pusat kegiatan.

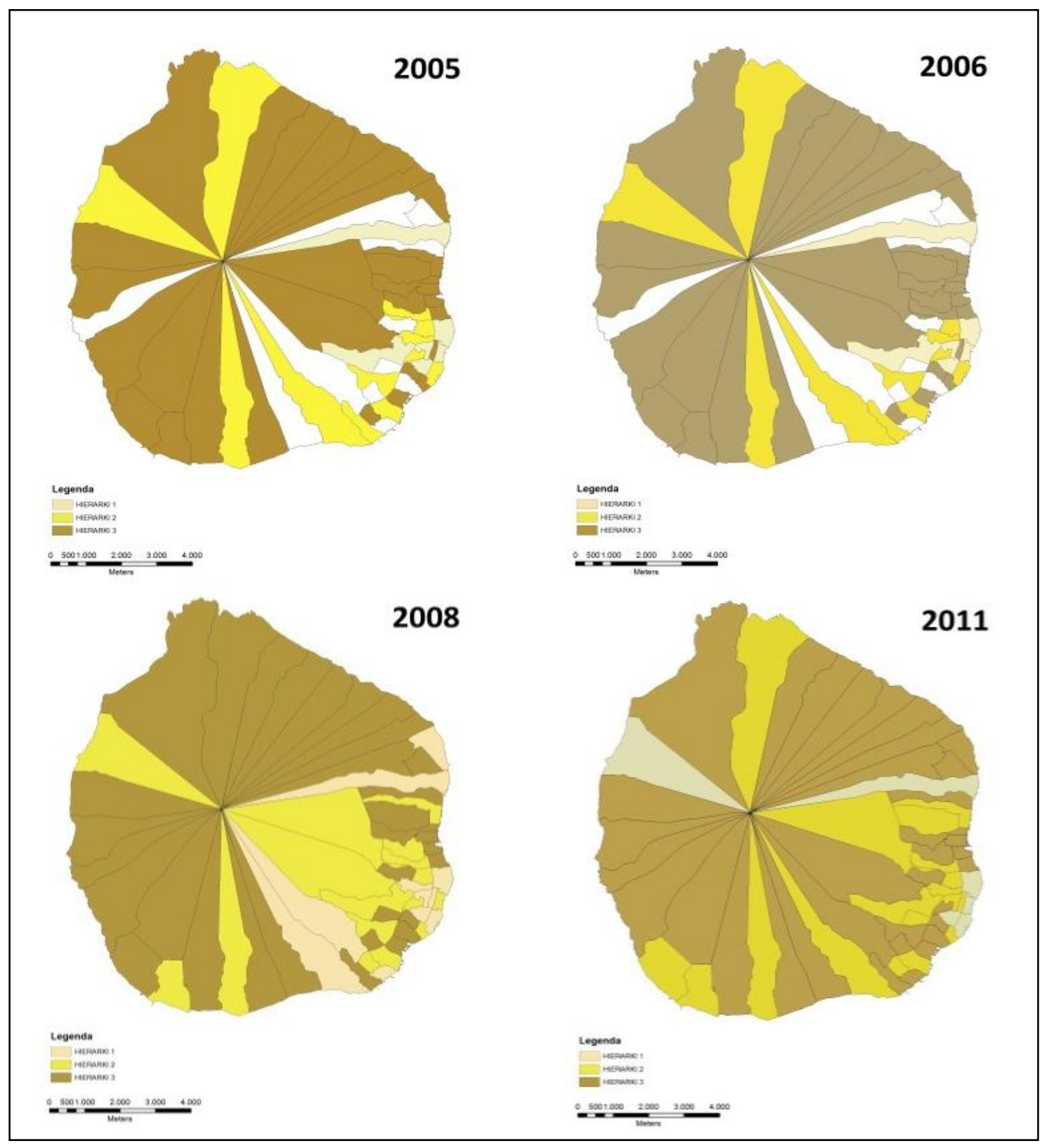

Sumber: Analisis Penulis, 2014

Gambar 4. Peta Hirarki Wilayah Kota Ternate 


\section{Hirarki Wilayah Kota Ternate Pasca Pengembangan Kawasan Waterfront City}

Pembangunan Kota Ternate ditujukan untuk meningkatkan dan mengembangkan kota dalam suatu sistem wilayah kepulauan melalui penyediaan dan peningkatan sarana dan prasarana (infrastruktur) yang dapat memberikan ciri sebagai kota pantai (waterfront city). Salah satu cirinya adalah terdapat 56 kelurahan pesisir dari total 77 kelurahan yang ada. Pergeseran jumlah penduduk yang bermukim di kawasan pesisir ikut ambil bagian dari perkembangan kota dalam pemenuhan sarana dan prasarana perkotaan.

Pengembangan kawasan waterfront di Kota Ternate diharapkan dapat meningkatkan pelayanan infrastruktur perkotaan. Pembangunan infrastruktur merupakan kebutuhan turunan sebagai konsekuensi logis dari perencanaan tata ruang, dimana infrastruktur sebagai pembentuk struktur ruang wilayah. Dengan demikian, rencana tata ruang yang ada dapat diwujudkan dalam bentuk pemanfaatan ruang yang sesuai dengan karakteristik wilayah dan dapat pula berfungsi sebagai pengendali pemanfaatan ruang.

\section{Kesimpulan}

Hasil analisis hirarki wilayah Kota Ternate tahun 2005-2011 menunjukkan bahwa telah terjadi perkembangan dari aspek ketersediaan sarana dan prasarana (infrastruktur) dan aksesibilitas. Kelurahan pesisir cenderung lebih berkembang dibandingkan dengan kelurahan bukan pesisir. Hal ini dapat dilihat dari perubahan tingkatan hirarki wilayah. Kelurahan/ desa pesisir yang tergolong dalam hirarki 1 (wilayah nodal/ pusat pelayanan) meningkat dari 3 kelurahan menjadi 6 kelurahan. Sementara itu, kategori kelurahan bukan pesisir terdapat 3 kelurahan berkurang menjadi 1 kelurahan. Kelurahan pesisir yang tergolong dalam hirarki 2 meningkat dari 7 kelurahan menjadi 8 kelurahan, dan kelurahan bukan pesisir juga meningkat dari 5 kelurahan meningkat menjadi 7 kelurahan. Kelurahan pesisir yang tergolong hirarki 3 (hinterland) menurun dari 22 kelurahan menjadi 18 kelurahan. Sedangkan kelurahan bukan pesisir tetap 8 kelurahan. Seiring perkembangan kawasan waterfront, banyak kelurahan pesisir yang ikut berkembang menjadi Pusat Pelayanan Kota (PPK)/ wilayah nodal yang melayani kebutuhan masyarakat Kota Ternate.

\section{Daftar Pustaka}

Adisasmita, R. (2015). Teori pertumbuhan kota. Yogyakarta: Graha Ilmu.

Badan Perencanaan Pembangunan Daerah (BAPPEDA) Kota Ternate. (2006). Rencana Tata Ruang Wilayah Kota Ternate 2006-2015. Ternate: BAPPEDA Kota Ternate.

Badan Pusat Statistik (BPS) Kota Ternate. (2005). Kota Ternate dalam angka 2005. Ternate: BPS Kota Ternate.

Badan Pusat Statistik (BPS) Kota Ternate. (2006). Kota Ternate dalam angka 2006. Ternate: BPS Kota Ternate.

Badan Pusat Statistik (BPS) Kota Ternate. (2008). Kota Ternate dalam angka 2008. Ternate: BPS Kota Ternate.

Badan Pusat Statistik (BPS) Kota Ternate. (2011). Kota Ternate dalam angka 2011. Ternate: BPS Kota Ternate.

Hu, Z., \& Lo, C. P. (2007). Modeling urban growth in Atlanta using logistic regression. Computers, Environment and Urban System, 31(6), 667-688. doi:10.1016/j.compenvurbsys.2006.11.001.

Mulyandari, H. (2010). Pengantar arsitektur kota. Yogyakarta: Penerbit Andi.

Mutlu, S. (1988). The spatial urban hierarchy in Turkey: Its structure and some its determinants. Growth and Change, 19(3), 53-74. doi:10.1111/j.1468-2257.1988.tb00475.x.

Nong, Y., \& Du, Q. (2011). Urban growth pattern modelling using logistic regression. Geo-spatial Information Science, 14(1), 62-67. doi:10.1007/s11806-011-0427-x.

Rustiadi, E., Saefulhakim, S., \& Panuju D. R. (2009). Perencanaan pengembangan wilayah. Jakarta: Crestpent Press dan Yayasan Obor Indonesia.

Tarigan, R. (2004). Ekonomi regional, teori dan aplikasi. Jakarta: PT. Bumi Aksara. 